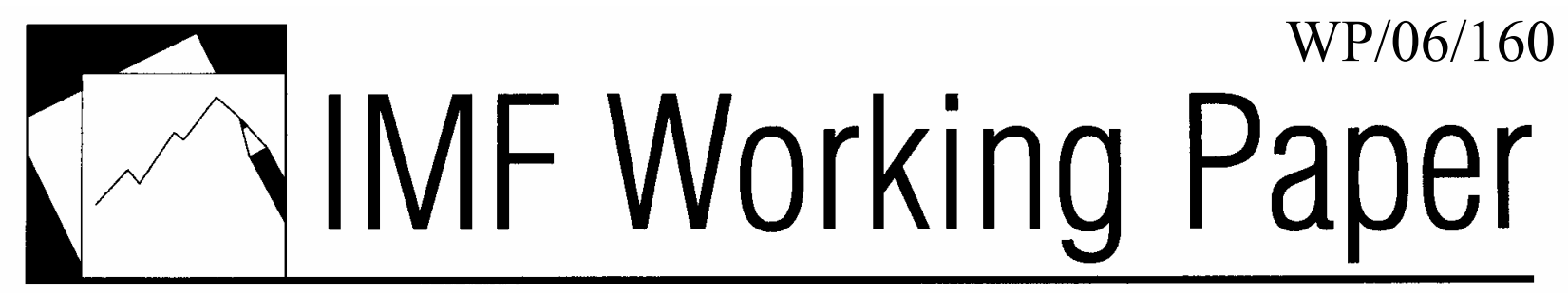

\title{
U.S. Dollar Risk Premiums and Capital Flows
}

Ravi Balakrishnan and Volodymyr Tulin 



\title{
IMF Working Paper
}

Western Hemisphere Department

\section{U.S. Dollar Risk Premiums and Capital Flows}

\section{Prepared by Ravi Balakrishnan and Volodymyr Tulin ${ }^{1}$}

Authorized for distribution by Tamim Bayoumi

June 2006

\begin{abstract}
This Working Paper should not be reported as representing the views of the IMF. The views expressed in this Working Paper are those of the author(s) and do not necessarily represent those of the IMF or IMF policy. Working Papers describe research in progress by the author(s) and are published to elicit comments and to further debate.

This paper sheds light on the attractiveness of U.S. assets by studying dollar risk premiums, calculated using Consensus exchange rate forecasts, and linking them to bilateral capital flows. The paper finds that the presence of negative dollar risk premiums (i.e. expectations of a dollar depreciation net of interest rate effects) amid record capital inflows could suggest that investors may favor U.S. assets for structural reasons. One possible explanation could be that the Asian crisis created a large pool of savings searching for relatively riskless investment opportunities, which were provided by deep, liquid, and innovative U.S. financial markets with robust investor protection. Moreover, the continued attractiveness of U.S. financial markets to European investors suggests that they offer a large array of assets, with different risk/return characteristics, that facilitate the structuring of diversified investment portfolios. Looking forward, this suggests that the allocative efficiency of U.S. financial markets could mitigate risks of a disorderly unwinding of global current account imbalances.
\end{abstract}

JEL Classification Numbers: E44, F31, F32, G15

Keywords: U.S. Dollar, Risk Premiums, Capital Flows

Author(s) E-Mail Address: rbalakrishnan@imf.org; vtulin@imf.org

\footnotetext{
${ }^{1}$ This paper has benefited from comments by our colleagues in the North American Division, Ashok Bhatia, and Calvin Schnure. Errors and omissions are the authors' sole responsibility.
} 
I. Introduction and Summary 3

II. What are Risk Premiums on the Dollar and How Can We Measure Them?.............. 4

A. Risk Premiums in an Uncovered Interest Parity Framework............................ 4

B. Dollar Risk Premium Estimates...................................................................... 6

III. Capital Flows and Risk Premiums .................................................................. 9

A. Measuring Bilateral Capital Flows .............................................................. 9

B. Links Between Capital Flows and Risk Premiums....................................... 12

IV. Explaining Risk Premium Movements .................................................................. 16

A. What Factors Could Drive Risk Premiums.................................................... 16

B. Regression Results .............................................................................. 17

V. Conclusions and Policy Implications ............................................................ 21

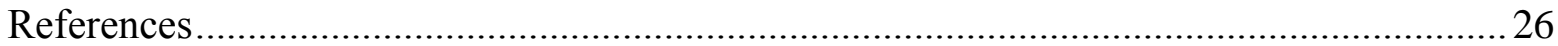

Tables

1. Bilateral Pairwise Granger Causality F-Tests ............................................... 7

2. Average Net Flows into U.S. Assets, 1995-99.................................................. 13

3. Average Net Flows into U.S. Assets, 2000-04................................................. 13

4. Average Gross Flows into U.S. Assets, 1995-99 ................................................ 14

5. Average Gross Flows into U.S. Assets, 2000-04 ............................................... 14

6. Foreign Holding of U.S. Long-Term Securities ................................................... 14

7. Euro Bilateral Risk Premium Regression Results ................................................. 19

8. Japanese Yen Bilateral Risk Premium Regression Results ................................... 20

9. British Pound Risk Premium Regression Results ................................................2 20

10. Canadian Dollar Risk Premium Regression Results.......................................... 21

11. Debt Securities Outstanding by Issuer ......................................................... 23

Figures

1. Current Account and Exchange Rate Developments........................................... 3

2. U.S. Dollar Risk Premiums Relative to Major Currencies ....................................... 8

3. U.S. Dollar Expected Appreciation Relative to Major Currencies ......................... 10

4. Interest Rate Differentials Relative to Major Currencies ...................................... 11

5. Narrow Risk Premium and the Current Account Deficit....................................... 9

6. Net Flows into U.S. Equity and Bonds ...................................................... 15

Appendix

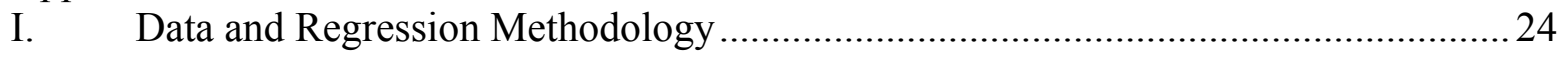

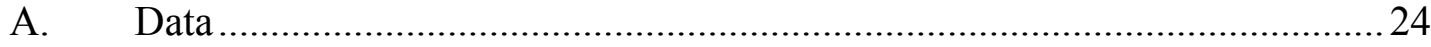

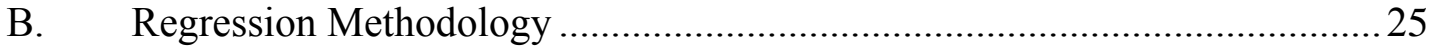




\section{INTRODUCTION AND SUMMARY}

Although the U.S. current account deficit has so far been easily financed, there remain questions about the availability of future financing. Following a largely steady deterioration since the early 1990s, the U.S. current account deficit reached a record $6 \frac{1}{2}$ percent of GDP in 2005 (Figure 1). The substantial increase in external financing, including both official and private inflows, has been provided without a major impact on U.S. interest rates or a trend weakening of the exchange rate. Nonetheless, with many professional forecasters expecting the deficit to widen further in the next few yearselevating concerns about the

Figure 1. Current Account and Exchange Rate Developments

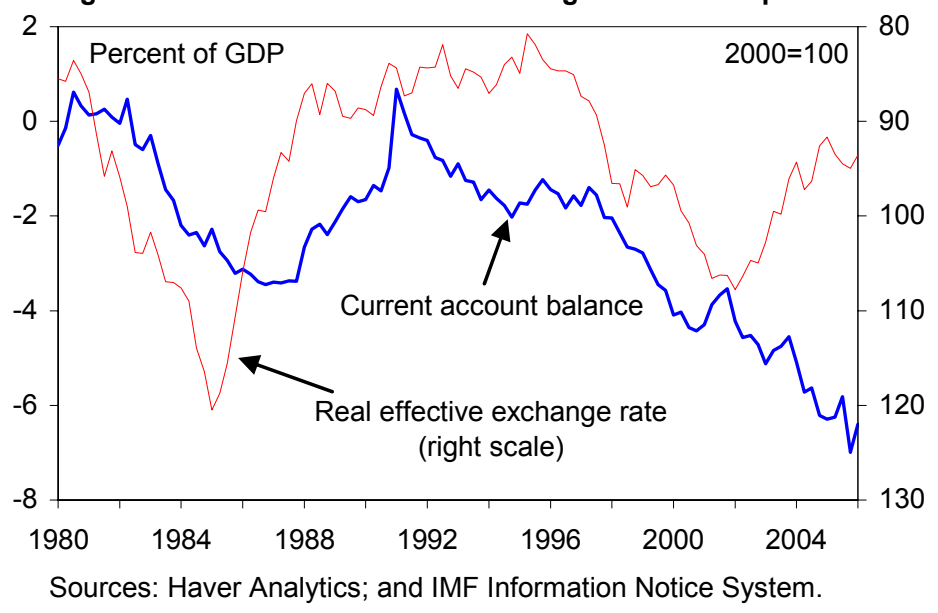
sustainability of the U.S. net foreign asset (NFA) position — questions remain as to how long such financing will last.

Against this background, many macroeconomic analysts consider the dollar overvalued. Even after it has experienced a depreciation of about 15 percent since the second quarter of 2002 in real effective terms, many studies still conclude that the dollar remains overvalued by $15-40$ percent. ${ }^{2}$ With increasing real and financial globalization, whether the depreciation will be orderly has important macroeconomic ramifications for not only the United States, but also the rest of the world (see IMF, 2006a, 2006b).

Another important question is whether the currently small interest differentials in favor of the United States are consistent with the perception that the dollar is significantly overvalued. Blanchard, Giavazzi and Sa (2005) and Krugman (2006) use portfolio balance models to suggest that annual real depreciation of 2-4 percent is needed along an orderly adjustment path. Yet as Krugman (2006) notes, long-term real interest rates in the United States are not 2-4 percentage points higher than in other major industrialized regions. Consequently, it appears that investors in these other regions, such as Japan and euro area countries, are holding U.S. bonds that offer a low or even negative rate of return in local currency terms. In other words, investors are accepting low or negative risk premiums on dollar assets. Is this irrational, and, if so, will the dollar have to depreciate faster than markets are currently expecting to make the U.S. NFA position sustainable?

\footnotetext{
2 IMF staff calculations produce a 15-35 percent range of overvaluation, with others, such as those of Obstfeld and Rogoff (2005) suggesting more than 30 percent.
} 
This paper analyzes these issues by studying in detail the behavior of risk premiums on U.S. assets. First, we estimate bilateral risk premiums on the U.S. dollar against various currencies using an uncovered interest parity framework and consensus exchange rate forecasts. These same currencies are also used to construct global risk premiums for the dollar. Second, we look at the link between capital flows and the measured risk premiums for various regions. Third, we try to explain what drives risk premium movements, by regressing the risk premium estimates on macroeconomic factors that have been suggested as drivers of sentiment. Finally, we try to draw some lessons about how global current account imbalances might be resolved.

Overall, we conclude that the presence of negative dollar risk premiums amid record capital inflows could suggest that investors may favor U.S. investments for structural reasons. In general, premiums fell into negative territory toward the end of the 1990s, but have since increased toward zero. Of course, markets could have simply been irrational in investing in U.S. assets despite negative expected returns, given prevailing interest rates and exchange rate expectations. Our analysis suggests another explanation, however-namely that the Asian crisis created a large pool of savings searching for relatively riskless investment opportunities, which were provided by deep, liquid, and innovative U.S. financial markets with robust investor protection. Moreover, the continued attractiveness of U.S. financial markets to European investors suggests that they offer a large array of assets, of different risk/return characteristics, that facilitate the structuring of diversified investment portfolios.

Looking ahead, the allocative efficiency of U.S financial markets could mitigate risks of a disorderly unwinding of global current account imbalances. Adverse adjustment scenarios would include a risk that foreign investors might buy fewer U.S. treasury bonds unless risk premiums on the dollar increase sharply, driving dollar depreciation as well as increases in relative interest rates in the United States. In particular, official flows into U.S. treasury bonds may decline as some major emerging market central banks approach their desired levels of reserves. The risks of such an adverse scenario, however, are likely to be reduced by the dollar's role as the global reserve currency and the continued attractiveness of the U.S. financial system. To be sure, for the latter characteristic to continue, U.S. financial markets will likely have to continue innovating to retain their advantage over other financial markets and, thus, provide foreign investors with the assets they desire. An "orderly" scenario would also be supported by (i) improving economic prospects and, consequently, increasing risk appetite in other regions, which should lead to a demand for riskier U.S. assets; and (ii) a continued reduction in home bias in Japan.

\section{What Are Risk Premiums on the Dollar and How Can We Measure Them?}

\section{A. Risk Premiums in an Uncovered Interest Parity Framework}

In its simplest form, arbitrage across two interest-bearing assets in different currencies by risk-neutral investors results in the well-known uncovered interest parity (UIP) condition: 


$$
\Delta s_{t, k}^{e}=i_{t, k}^{f}-i_{t, k}^{d}
$$

where $\Delta s_{t, k}^{e}$ is the expected (per period) change in the spot exchange rate ${ }^{3}$ between $t$ and $t+k$, $i_{t, k}^{f}$ is the nominal interest rate on a foreign bond of maturity $k$ at time $t$, and $i_{t, k}^{d}$ is the nominal interest rate on a local bond of maturity $k$ at time $t$.

Even risk-neutral investors, however, could demand compensation for different default probabilities, transactions costs, taxation, and liquidity across assets. Generally speaking, between industrialized countries' government debt, any differences in default risk or transaction costs tend to be small. For emerging market countries, however, particularly if the capital account is not fully liberalized or during crisis periods, such factors can vary substantially.

If investors are risk averse, they will also demand compensation for the risk of exchange rate changes or a foreign exchange risk premium, $f x r p_{t, k}$. This can be interpreted as the extent to which exchange rate movements help smooth out investors' consumption patterns over time. Indeed, consumption capital asset pricing models (C-CAPM) (see Cochrane 2001) suggest that

$$
\operatorname{fxrp}_{t, k}=-\operatorname{cov}_{t}\left(\Delta s_{t+k}, m_{t+1}\right)
$$

Where $m_{t+1}$ is the nominal stochastic discount factor (SDF). In real terms, the SDF is the discounted ratio of the expected future and present marginal utilities of consumption. For a standard concave utility function, the risk premium will be negative if the domestic currency appreciates when consumption of the representative investor falls, since domestic currency assets are helping hedge against consumption volatility.

We call the sum of what can drive a wedge between the expected exchange rate change and interest differential the risk premium, $r p_{t}$. Thus, the UIP condition becomes:

$$
\Delta s_{t, k}^{e}=i_{t, k}^{f}-i_{t, k}^{d}+r p_{t . k}
$$

A negative risk premium implies that foreign investors accept a negative expected return by investing in U.S. assets, given prevailing interest rates and exchange rate expectations. In other words, they are willing to hold a U.S. bond despite it offering a negative expected rate of return in local currency terms.

\footnotetext{
${ }^{3}$ Defined as foreign currency per unit of domestic currency.
} 
More recently, other reasons have also been suggested for the small interest premium on U.S. assets. The dollar's role as the global reserve currency and "safe haven" effects are wellknown factors. As the dollar appreciated significantly in the late 1990s, however, despite a large and growing current account deficit, analysts pointed to a combination of other factors that may have led to strong U.S. capital inflows: (i) higher growth prospects in the United States relative to the euro area and Japan, making investing in the United States more attractive; (ii) deep, liquid, and innovative U.S. financial markets, which have securitized a wide array of risky assets and facilitated risk transfer; and (iii) a global savings glut, as highsaving Asian nations searched for investment opportunities after the financial crises of the 1990s reduced investment opportunities in Asia.

\section{B. Dollar Risk Premium Estimates}

Using equation (3) to measure risk premiums, we need data on interest rate differentials and forecasts of future exchange rates. For interest rates, we use Eurocurrency deposit rates where possible and generic government bond rates from Bloomberg otherwise. For exchange rate forecasts, we use survey data from Consensus Economics. Since 1989, Consensus Economics have produced monthly exchange rate forecasts across a range of currencies at 3 month and 12 month horizons. In the mid-1990s, they started producing 2-year ahead exchange rate forecasts. Currently, they survey more than 250 financial and economic forecasters and cover 90 currencies. Thus, the sample is extremely rich and allows us to construct risk premium estimates across a slew of dollar bilaterals at three month, one year, and 2 year horizons for both industrialized and emerging market countries. Further details of the construction of the risk premium estimates are given in Appendix I.

Although there are important caveats to the use of survey data on exchange rates, the consensus forecasts appear good proxies of investor sentiment. There are studies suggesting that survey data can deliver biased forecasts of exchange rates and thus appear to be incompatible with rational expectations (see Chinn and Frankel 1994 and Bofinger and Schmidt 2004). However, as noted by Lewis (1989), unbiasedness is implied by rational expectations only if there is agreement on the true model. Given that most well-known models of exchange rates forecast poorly, it seems clear that this does not hold. Thus, survey data expectations could be rational despite delivering biased forecasts - especially when peso problems and learning behavior are taken into account. In terms of estimating risk premiums using UIP - an ex ante condition — all that matters are whether the consensus forecasts are good proxies for investor sentiment, and to the extent that the consensus forecast is the mean of the forecast of numerous professional forecasters this should be the case. ${ }^{4}$

\footnotetext{
${ }^{4}$ Indeed, for May 2006, 116 professional forecasters were surveyed for the euro-dollar forecast. To be sure, especially with respect to exchange rate forecasts, individual market participants can have widely differing views, potentially leading to different risk premium estimates for each participant. Notwithstanding this, the presumption of this paper is that the consensus forecast captures overall market sentiment.
} 
Also in support of the use of consensus forecasts, there is no evidence to suggest that actual capital flows or exchange rate changes help explain the constructed risk premiums. One concern with the risk premium calculation is that Consensus exchange rate forecasts might simply reflect an extrapolation of recent trends in markets rather than an assessment of future trends in currencies. Reassuringly against this, granger causality tests indicate that movements in the spot rate, or indeed capital flows, do not predict risk premiums, and thatif anything - the risk premiums have some predictive power on future movements in the spot rate (Table 1).

\begin{tabular}{|c|c|c|c|c|}
\hline & Canada & Japan & Euro Area & $\begin{array}{c}\text { United } \\
\text { Kingdom }\end{array}$ \\
\hline Actual depreciation (from a year ago until now) does not cause current level of risk premium & $2.522 *$ & 0.975 & 0.688 & 0.799 \\
\hline Risk premium does not cause future realized depreciation (from now until one year in the future) & 1.385 & $3.030 * *$ & $2.296 * *$ & $3.503 * *$ \\
\hline
\end{tabular}

The measured risk premiums have large persistent swings, especially for the yen and euro. Figure 2 plots the annualized dollar risk premium estimates at one and two year horizons against the British pound sterling, the Canadian dollar, the euro, and the yen. In general, risk premiums declined toward the end of the 1990s but have increased toward zero since. The risk premium on the euro remarkably declined to about -10 percent in $2000 .^{5}$ While the risk premium on the yen has generally been positive, it has turned negative in the last couple of years - consistent with studies which find that Japanese home bias declining from extremely high levels in the past (IMF, 2005).

Global risk premium measures confirm that the risk premium turned negative in the late 1990s, reaching a low in 2001, and has increased toward zero since. To get an overall picture, global narrow and broad measures of the risk premium, which weight the bilateral risk premiums by the average of respective country import and export shares in the United States, were constructed. The narrow measure includes the British pound sterling, the Canadian dollar, the euro, and the yen; and the broad measure — available only from 2000 — adds to this a basket of emerging market currencies. The broad measure of risk premium has generally

\footnotetext{
${ }^{5}$ Of course, actual exchange rate movements can be substantial as well. For example, in 2000, the dollar appreciated by over 15 percent against the euro.
} 


\section{Figure 2. U.S. Dollar Risk Premiums Relative to Major Currencies ${ }^{1}$}

in 1 year

British Pound

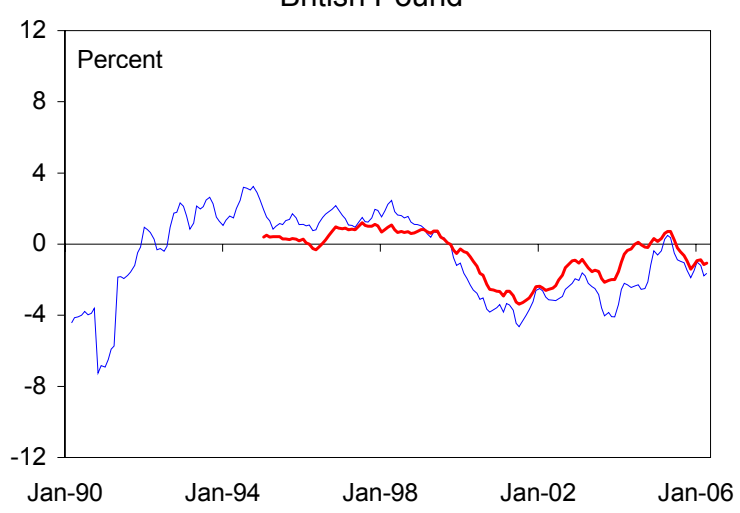

Japanese Yen

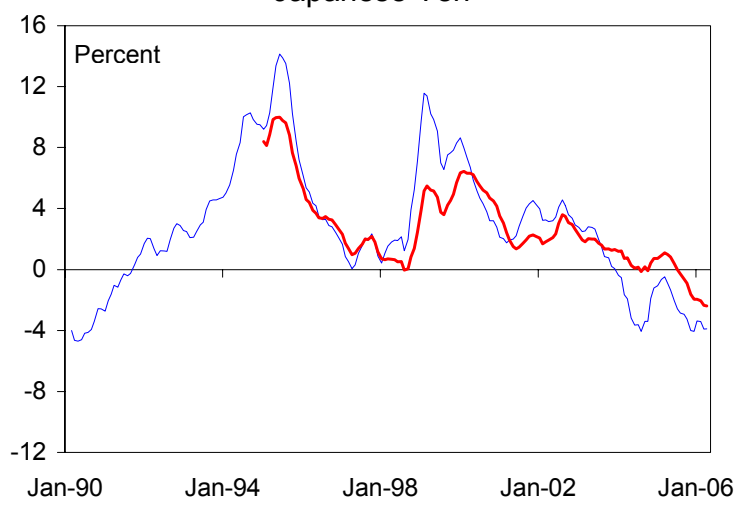

Narrow Measure

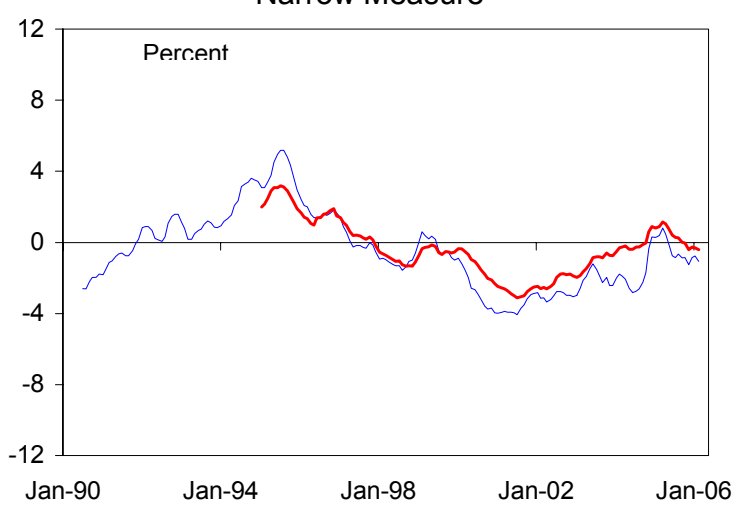

in 2 years
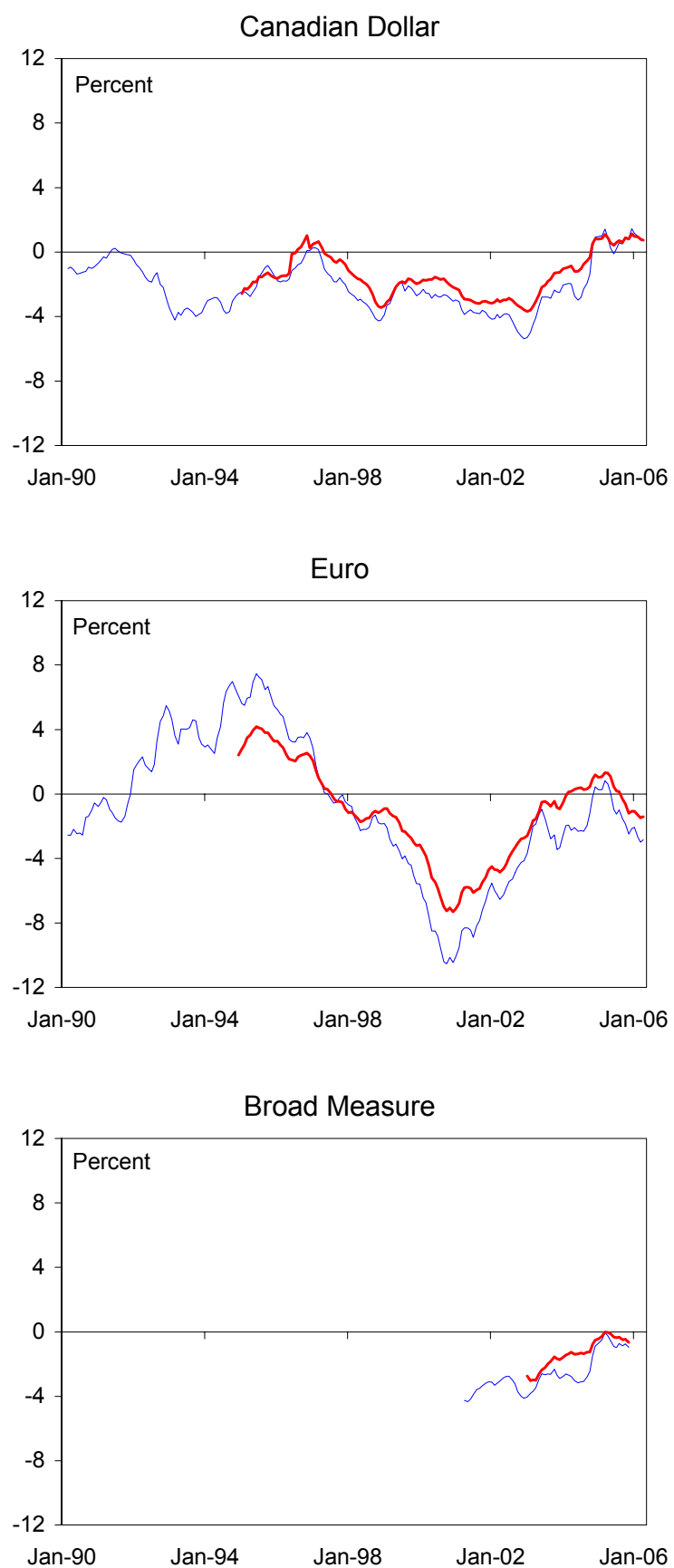

Sources: Bloomberg; Consensus Economics; Datastream; Haver Analytics; and IMF staff calculations.

${ }^{1}$ Annualized, 6-month moving average. 
been lower than the narrow measure, likely reflecting default and liquidity premiums, and transactions costs, which can be more significant for emerging market currencies.

In recent years, risk premium movements reflect both large swings in expected exchange rate changes and the extraordinary increase and subsequent withdrawal of monetary stimulus in the United States (Figures 3-4). While the large swings in exchange rate expectations are the major contributor to the volatility of risk premium estimates, especially for the euro/dollar, changes in interest rate differentials have also played significant role. Indeed, the cumulative reduction in the Fed Funds rate by 550 basis points during December 2000-June 2003 and the subsequent increase of 400 basis points have contributed importantly to the general increase and decline in U.S premiums. High interest rate differentials in favor of the United States compared to Japan across time also largely explain why the risk premium against the yen has been generally positive.

Over the last year, some risk premiums have turned negative as increasing expectations of dollar depreciation have only been partly offset by growing interest differentials in favor of the United States. In particular, against the euro and the yen the annualized expected depreciation is sizable and growing at the one year and two year horizons. Interestingly, the annualized expected depreciation over 2 years has generally been less than over a year, which could be consistent with markets expecting a fairly orderly dollar depreciation.

\section{Capital Flows and Risk Premiums}

The extraordinary rise in capital flows despite the presence of negative risk premiums raises important questions. Risk premiums declined and even turned negative at the same time as the current account deficit deteriorated (Figure 5). To investigate further what could have caused this, we study bilateral capital flow data.

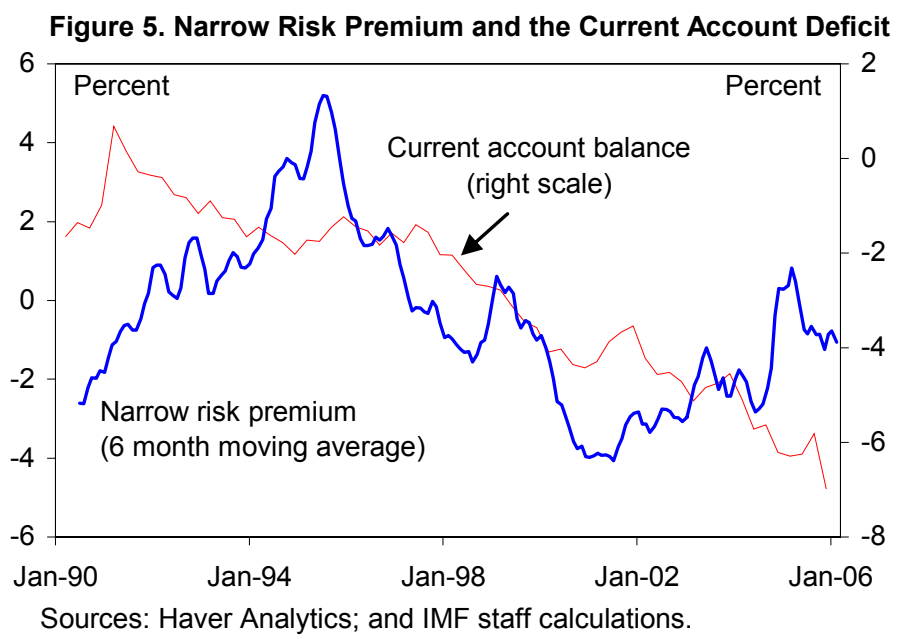

\section{A. Measuring Bilateral Capital Flows}

The main data on bilateral capital flows comes from the Treasury International Capital (TIC) system. The TIC system records monthly transactions involving U.S. residents and foreigners, mainly reported by brokers and dealers. On the liabilities side, long-term securities are classified into equities, as well as corporate, 
Figure 3. U.S. Dollar Expected Appreciation Relative to Major Currencies ${ }^{1}$
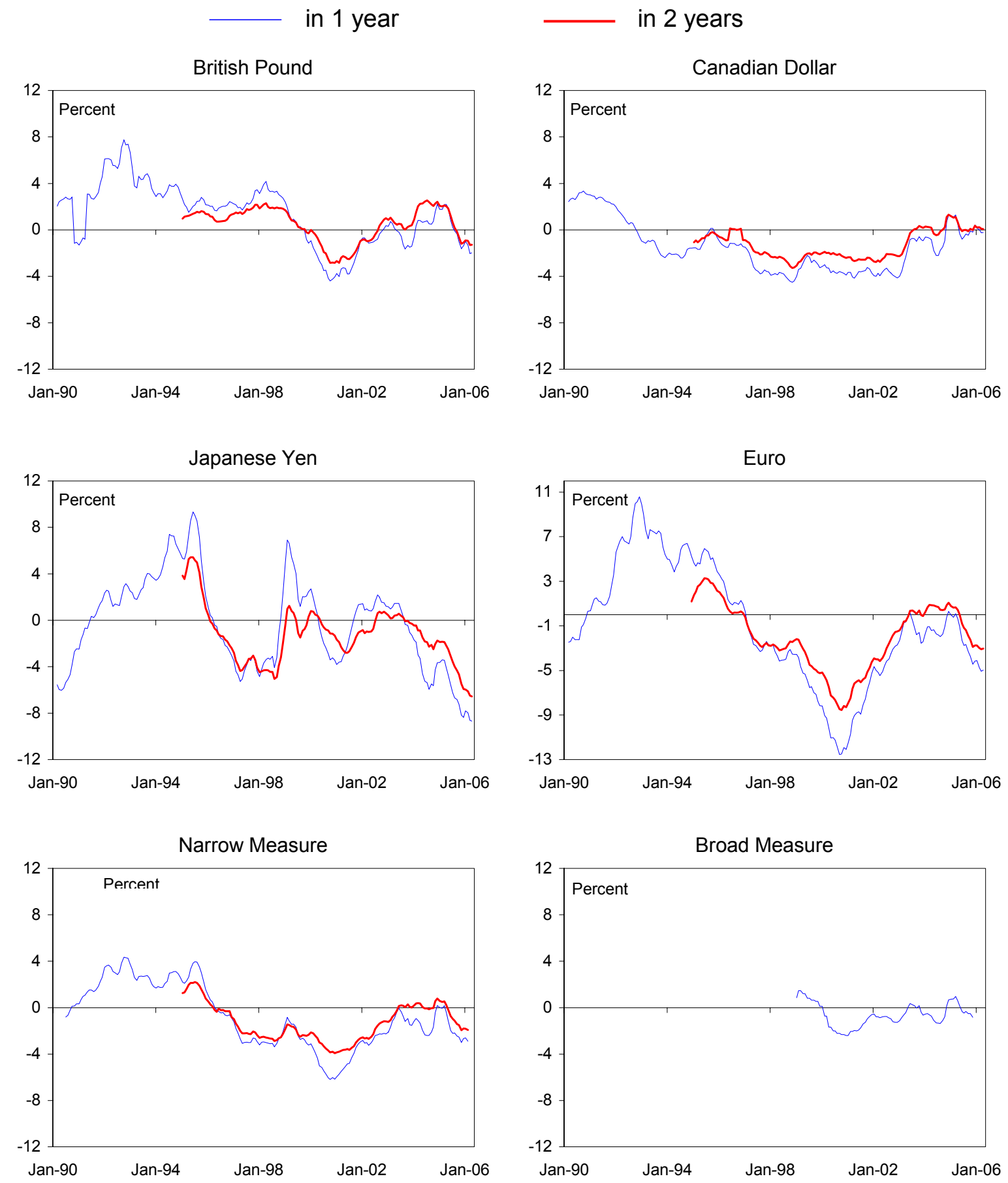

Sources: Bloomberg; Consensus Economics; Datastream; Haver Analytics; and IMF staff calculations.

${ }^{1}$ Annualized, 6-month moving average. Increase signifies U.S. dollar appreciation. 
Figure 4. Interest Rate Differentials Relative to Major Currencies ${ }^{1}$

$\longrightarrow$ in 1 year

British Pound

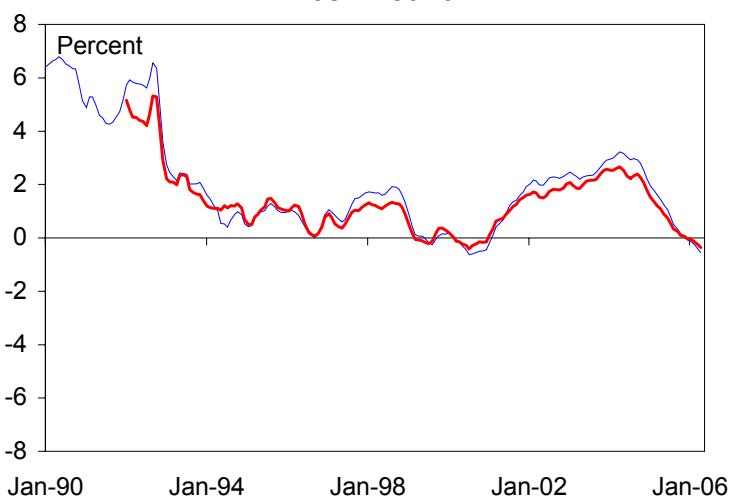

Japanese Yen

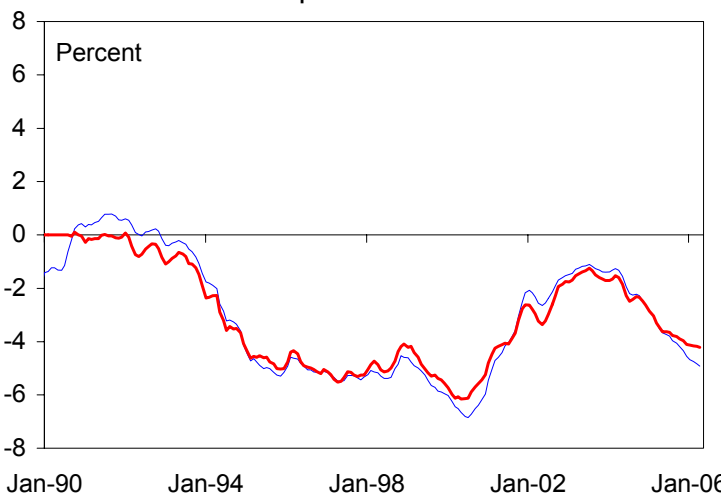

Narrow Measure

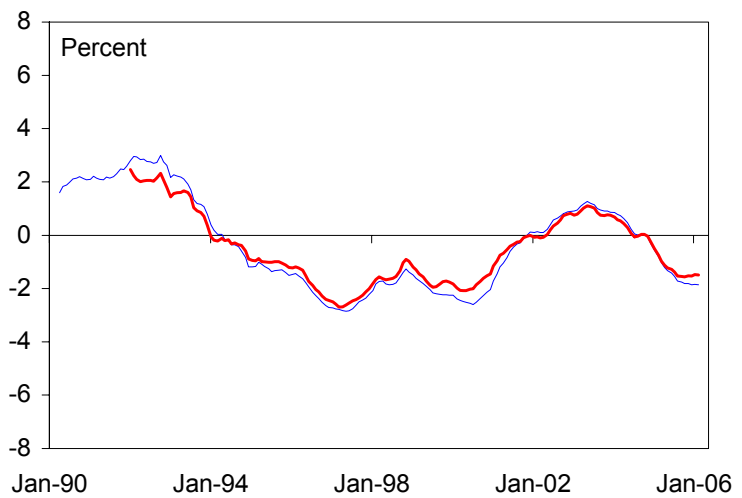

in 2 years

Canadian Dollar

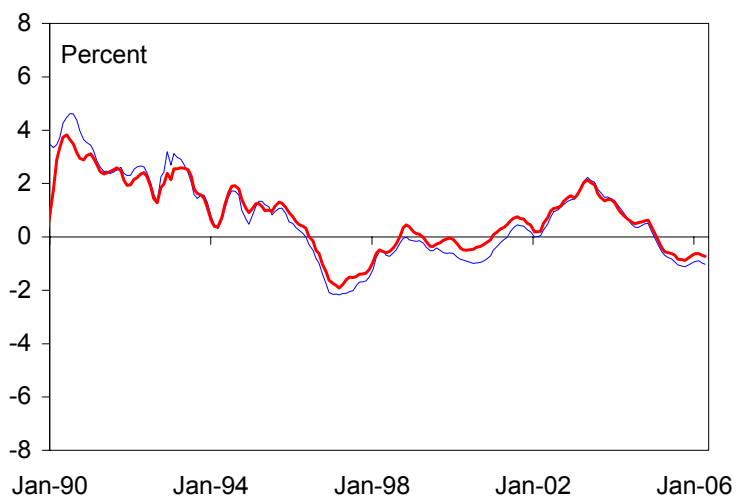

Euro

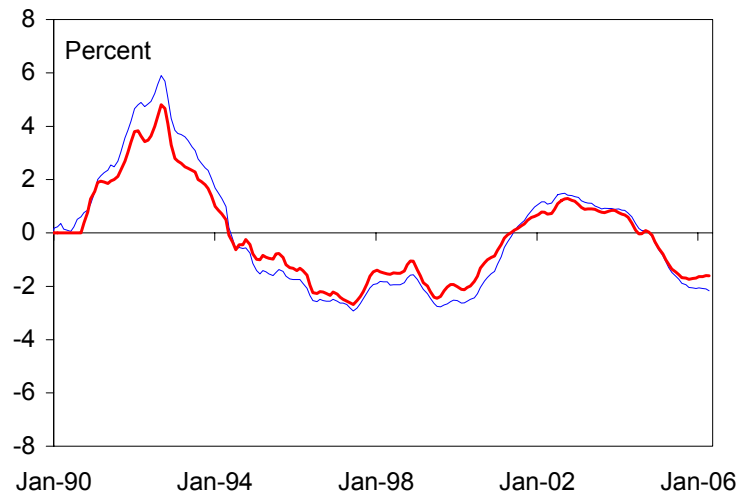

Broad Measure

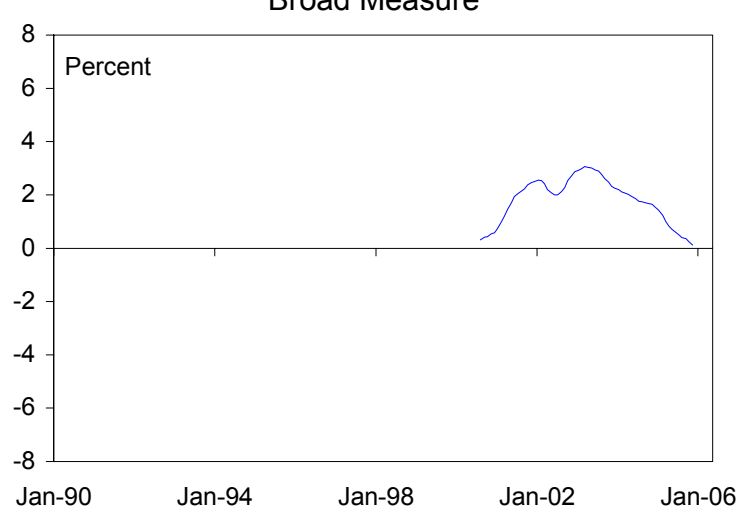

Sources: Bloomberg; Consensus Economics; Datastream; Haver Analytics; and IMF staff calculations.

${ }^{1}$ Annualized, 3-month moving average. 
agency, and treasury bonds. On the asset side, they are only classified into equities and bonds. However, as is well known (see Warnock and Cleaver 2002), TIC monthly transactions data are less accurate than custodial data such as reported in infrequent TIC benchmark surveys of U.S. assets and liabilities. In particular, there is a strong financial center bias in country attribution as the monthly data indicate the country through which investors purchase securities and not necessarily the ultimate owner of securities. ${ }^{6}$

To mitigate financial center bias, we use benchmark consistent TIC reported flows. We follow the methodology employed by Thomas, Warnock, and Wongswan (2006) and Chinn, Rogers, and Warnock (2006) in making use of information contained in the comprehensive benchmark surveys of U.S. assets and liabilities. Essentially, a correction is applied to the raw bilateral TIC flows so that when they are accumulated, adjusting for valuation changes, they give the same stocks of assets and liabilities as published in the benchmark surveys. ${ }^{7}$ In other words, they are benchmark consistent flows. ${ }^{8}$

\section{B. Links Between Capital Flows and Risk Premiums}

Most of the increase in net flows to finance the widening current account deficit has come from the euro area, Japan, and emerging Asia; and gone into bonds. ${ }^{9}$ For both the periods 1995-99 and 2000-2004, net bond flows were significantly higher than net equity flows, with the latter even being negative on average during the 1995-99 despite the stock market boom in the United States (Tables 2-3). The euro area was the biggest net investor in the United States during the whole period 1995-2004, with Japan and emerging Asia also being significant investors, particularly during 2000-2004..$^{10}$

\footnotetext{
${ }^{6}$ For example, if the Bank of China instructed a private bank in London to buy U.S. Treasury bonds from a U.S. resident, this would show up in the TIC system as a treasury bond flow from the United States to the United Kingdom.

${ }^{7}$ We thank Frank Warnock for providing us with the benchmark consistent TIC data, and readers interested in further details are referred to the aforementioned papers.

${ }^{8}$ As noted in Warnock and Cleaver (2002), however, although benchmark surveys of U.S. assets should not suffer from financial center bias, surveys of U.S. liabilities probably do. This is because the identifier on a U.S. security provides only information on the custodian, which is not necessarily in the country of the actual owner of the security. Nonetheless, the bias is significantly less than in the raw monthly TIC data.

${ }^{9}$ Emerging Asia includes China, Hong Kong SAR, India, Indonesia, the Republic of Korea, Malaysia, the Philippines, Singapore, Taiwan Province of China, Thailand. Latin America excludes the Caribbean, which is included in "other".

10 "Other" was also significant, but that is mainly because it includes offshore financial centers in the Caribbean, through which substantial investments into U.S. assets from the rest the world, and indeed from U.S investors to the rest of the world, are likely channeled.
} 


\begin{tabular}{|lrrr|}
\hline \multicolumn{4}{c|}{$\begin{array}{r}\text { Table 2. Average Net Flows into U.S. Assets, 1995-99 } \\
\text { (In billions of U.S. dollars per year) }\end{array}$} \\
\hline & Bonds & Equity & Total \\
\cline { 2 - 4 } Canada & -4.4 & 1.2 & -3.2 \\
Emerging Asia & 31.7 & -13.4 & 18.4 \\
Euro area & 23.0 & 11.3 & 34.3 \\
Japan & 16.2 & -25.1 & -8.9 \\
Latin America & 0.7 & -3.5 & -2.8 \\
United Kingdom & 18.8 & 1.1 & 19.9 \\
Other & 65.3 & -35.0 & 30.3 \\
\hline Total & 155.8 & -64.5 & 91.3 \\
\hline
\end{tabular}

\begin{tabular}{|lrrr|}
\hline \multicolumn{4}{c|}{$\begin{array}{r}\text { Table 3. Average Net Flows into U.S. Assets, 2000-2004 } \\
\text { (In billions of U.S. dollars per year) }\end{array}$} \\
\hline & Bonds & Equity & Total \\
\cline { 2 - 4 } Canada & 4.2 & 14.5 & 18.7 \\
Euro area & 114.7 & 40.6 & 155.2 \\
Emerging Asia & 90.1 & 0.7 & 90.8 \\
Japan & 101.3 & -9.1 & 92.2 \\
Latin America & 7.7 & 0.0 & 7.7 \\
United Kingdom & -2.1 & -7.6 & -9.7 \\
Other & 180.1 & 74.4 & 254.5 \\
\hline Total & 377.2 & 58.4 & 435.6 \\
\hline
\end{tabular}

Data on gross flows into the United States show large flows into corporate bonds but that investment patterns differ significantly across regions. As noted earlier, TIC data on U.S liabilities allow a finer distinction of bond flows, splitting them into treasury, agency, and corporate bond flows. While agency bond flows showed the biggest increase in percentage terms from 1995-99 to 2000-2004, corporate bond flows were the largest in absolute terms over 1995-2004 (Tables 4-5). European investors mainly acquired corporate bonds and equity, whereas Japan and emerging Asia invested primarily into treasury bonds, largely confirming the findings of Brooks, Edison, Kumar, and Sløk (2001). The coincidence of riskier investment patterns and - on occasion - strongly negative risk premiums in the eurodollar exchange rate suggests that European investors may have had a greater risk appetite than Asian investors as far as U.S. assets are concerned-something we will discuss further in Section IV. 


\begin{tabular}{|lrcrrr|}
\hline \multicolumn{5}{c|}{$\begin{array}{c}\text { Table 4. Average Gross Flows into U.S. Assets, 1995-99 } \\
\text { (In billions of U.S. dollars per year) }\end{array}$} \\
\hline & Treasury Bonds & Agency Bonds & Corporate Bonds & Equity & Total \\
\cline { 2 - 6 } Canada & 1.3 & 0.9 & 2.1 & -1.6 & 2.7 \\
Emerging Asia & 25.0 & 8.8 & 0.9 & 0.1 & 34.8 \\
Euro area & 10.3 & 5.6 & 18.7 & 24.2 & 58.7 \\
Japan & 17.6 & 0.6 & -2.0 & 5.1 & 7.3 \\
Latin America & 4.0 & 1.5 & 1.8 & 0.2 & 29.5 \\
United Kingdom & 8.5 & 4.2 & 46.3 & 1.4 & 71.5 \\
Other & 18.0 & 5.6 & 81.4 & 32.2 & 223.4 \\
\hline Total & 83.4 & 26.3 & & \\
\hline
\end{tabular}

\begin{tabular}{|c|c|c|c|c|c|}
\hline \multicolumn{6}{|c|}{$\begin{array}{l}\text { Table 5. Average Gross Flows into U.S. Assets, 2000-2004 } \\
\text { (In billions of U.S. dollars per year) }\end{array}$} \\
\hline & Treasury Bonds & Agency Bonds & Corporate Bonds & Equity & Total \\
\hline Canada & 2.0 & -0.4 & 6.9 & 13.7 & 22.2 \\
\hline Euro area & 1.2 & 19.6 & 104.3 & 50.6 & 175.7 \\
\hline Emerging Asia & 37.8 & 33.4 & 11.0 & 15.2 & 97.4 \\
\hline Japan & 73.7 & 13.2 & 14.7 & 11.9 & 113.5 \\
\hline Latin America & 2.0 & 0.7 & 7.2 & 3.5 & 13.5 \\
\hline United Kingdom & -5.2 & 2.0 & 24.8 & 6.3 & 27.9 \\
\hline Other & 23.7 & 37.3 & 124.0 & 121.6 & 306.7 \\
\hline Total & 132.1 & 86.6 & 181.7 & 158.5 & 558.9 \\
\hline
\end{tabular}

Stock data show that asset-backed securities (ABSs) are increasingly being bought by foreigners. The agency bond and corporate bond categories include asset backed securities. However, while the flow data does not allow one to see how much has been invested in ABSs, the benchmark surveys of foreign holdings of U.S. securities provides such information. As shown in Table 6, agency and corporate ABSs have increased both in dollar terms and as a share of security class in recent years.

\begin{tabular}{|c|c|c|c|c|}
\hline \multicolumn{5}{|c|}{ Table 6. Foreign Holding of U.S. Long-Term Securities } \\
\hline & \multicolumn{2}{|r|}{ Agency Debt } & \multicolumn{2}{|c|}{ Corporate Debt } \\
\hline & In billions of U.S. dollars & $\begin{array}{c}\text { of which Asset-Backed Securities } \\
\text { (percent of total) }\end{array}$ & In billions of U.S. dollars & $\begin{array}{l}\text { of which Asset-Backed Securities } \\
\text { (percent of total) }\end{array}$ \\
\hline 2002 & 492 & 25.4 & 1,130 & 14.9 \\
\hline 2004 & 623 & 28.3 & 1,429 & 19.3 \\
\hline 2005 & 786 & 33.0 & 1,734 & 26.4 \\
\hline
\end{tabular}

Bilateral flows data reaffirm that capital flows increased from most regions despite risk premiums turning negative (Figure 6). The exception is for flows from the United Kingdom, 
Figure 6. Net Flows into U.S. Equity and Bonds
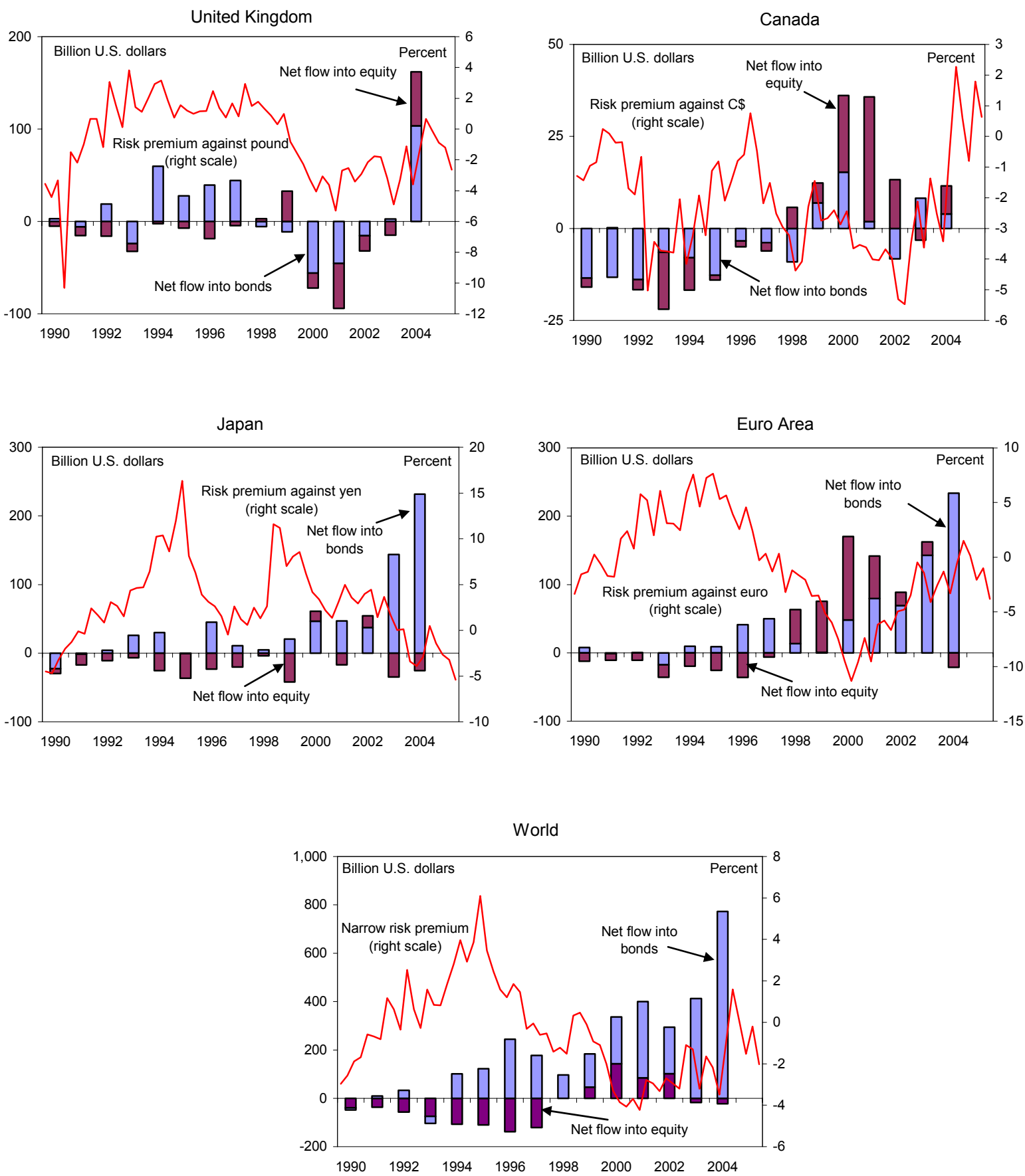

Sources: Consensus Economics; Datastream; Haver Analytics; and IMF staff calculations. 
though even these were extremely high in 2004 despite a negative risk premium. ${ }^{11}$ This suggests that other structural factors are helping drive capital flows apart from interest differentials on government debt and expected exchange rate changes. In the next section we will try to explain what these other factors could be.

\section{Explaining Risk Premium Movements}

\section{A. What Factors Could Drive Risk Premiums?}

To investigate what drives risk-premium movements, we regress our risk-premium estimates for the major currencies against key macroeconomic factors. The data are quarterly and cover the period from 1995 to 2004, (Appendix I has full details of how the variables were constructed and the regression methodology.) Based on the analysis of Sections II-III, we considered several broad factors that could be key explanatory variables of risk premiums:

- $\quad$ Sustainability of the U.S. external position. The long-term sustainability of the U.S. current account balance has been debated from as far back as the late 1990s (see Cerisola, Faruqee, and Keenan (1999)), since when the deficit has risen substantially. To the extent that investors have concerns about this, they may demand a risk premium on U.S assets for the possibility of a "disorderly" adjustment to the dollar ("tail risk"). We consider three measures of sustainability: (i) the NFA of the United States relative to the country being considered, following the methodology outlined in IMF (2005) to construct quarterly observations; (ii) the absolute NFA position of the United States; and (iii) the U.S. net portfolio asset position as constructed from the benchmark consistent capital flows dataset.

- $\quad$ Relative growth prospects. As mentioned in Section II, many commentators have argued that better U.S. growth prospects have led to expectations of higher returns from investing in the United States, which have driven capital flows. To test whether this has had an effect on risk premiums, we construct different measures of relative growth prospects using: (i) relative consensus growth forecasts; (ii) relative OECD leading indicators; (iii) relative average growth outturns; and (iv) relative stock market returns, which capture market beliefs as to the future profitability of firms. ${ }^{12}$ In

\footnotetext{
${ }^{11}$ It should also be noted that to the extent that there is any residual financial center bias in the benchmark consistent flows, the bias is likely to be more significant for flows from the United Kingdom given that it is one of the most important financial centers. For example, flows to and from oil exporters, which are difficult to track through the TIC system, may be an important component of net flows identified as coming from the United Kingdom.

12 The Organization of Economic Cooperation and Development (OECD) has compiled Composite Leading Indicators (CLIs) since the beginning of the 1980s for 22 member countries (http://www.oecd.org/std/cli). The CLIs are aggregate time series that show a leading relationship with the growth cycles of key macro-economic indicators (the average lead is 6 months). Typically, they are constructed to predict the cycles of total industrial production or gross domestic product in industry, which are chosen as proxy measures for the aggregate economy. CLIs are calculated by combining component series in order to cover, as far as possible, the key sectors of the economy. These component series cover a wide range of short-term indicators, such as observations or opinions about economic activity, housing permits, and financial and monetary data.
} 
principle, we should not expect a large effect, given that risk premiums are estimated using UIP on interest bearing assets - bonds usually have a fixed nominal interest rate, and so relative growth prospects should not affect the risk premium, unless it changes default risk, which should not be significant for the industrialized country exchange rates considered.

- $\quad$ Measures of risk appetite. As documented in subsection III.B, euro area investors appear to have a significantly higher appetite for risk than Asian investors. This could be related to the financial crises in Asia in the 1990s, and strong home bias of Japanese investors compounded by the deflation of the 1990s. To test if this is an important factor, we construct a measure of risk preference that is a country's stock of U.S treasury bonds as a share of its total holdings of U.S bonds. If this ratio increases, it signifies that a country is becoming more risk averse as its portfolio of U.S assets is increasing in treasury bonds at the expense of riskier securities. ${ }^{13}$

- $\quad$ Asian crisis. Many authors (including Caballero, Farhi, and Gourinchas, 2006 and Gruber and Kamin, 2005) have argued that the financial crises in high-saving Asia nations in the late 1990s contributed to subsequent capital outflows from that region, and thus to what Bernanke (2005) called a "global savings glut". We try to capture this by including a dummy for the period after the Asian crisis.

- $\quad$ The C-CAPM foreign exchange rate risk premium. As discussed in subsection II.B, this is given by $\operatorname{fxrp}_{t, k}=-\operatorname{cov}_{t}\left(\Delta s_{t+k}, m_{t+1}\right)$. Although the form of the SDF depends on the utility function of the representative investor, with most representations it will be a function of consumption growth (Cochrane 2001). However, as Campbell (1993) notes, consumption patterns of asset market participants may be poorly proxied by aggregate consumption. With this is mind, and following the literature based on the intertemporal capital asset price model (ICAPM) of Merton (1973), we proxy consumption of asset market participants by an aggregate stock market return. In particular, we use the return on the MSCI global equity index as a proxy for the consumption of a representative "world" investor (see Ayuso and Restoy, 1996 and Balakrishnan and Groen, 2006). We measure the covariance using monthly data over the previous two years.

\section{B. Regression Results}

Neither sustainability concerns, a foreign exchange risk premium, nor relative growth prospects appear to have driven risk premiums movements. Tables $7-10$ present the basic

\footnotetext{
${ }^{13}$ We also check the robustness of the results to this measure be constructing a similar measure that includes agency bonds in the numerator, given that such bonds are perceived by markets to come with a government guarantee.
} 
regression results for the risk premiums on the British pound sterling, the Canadian dollar, the Japanese yen, and the euro:

- $\quad$ Sustainability. This variable is generally insignificant except for some specifications for the euro (correctly signed) and most specifications for the yen (wrongly signed). The lack of significance or wrong sign probably reflect that risk premiums declined across all currencies as the relative NFA position of the United States deteriorated substantially. This suggests that up until now, investors have not been concerned about the sustainability of the U.S. NFA position above and beyond the impact it has on their baseline forecast of dollar movements. Wadhwani (1999) finds a similar result for the United Kingdom.

- $\quad$ Relative growth prospects. The relative consensus forecast and average growth outturn measures are significant for all currencies except the British pound sterling but have the wrong sign. The other measures are generally insignificant. The wrong sign is puzzling, but probably reflects that recent increases in risk premiums took place at the same time as growth differentials moved in favor of the United States.

- $\quad C-C A P M$ foreign exchange risk premiums. This variable is insignificant for most currencies, except in the case of the yen, when it is usually significant but wrongly signed. Two possible reasons for this are: (i) investors main concern may not be stabilizing their own consumption volatility; and (ii) an MSCI global equity index is not a good proxy of consumption of a representative "world" investor. As noted by Lettau and Ludvingson (2001), even as a simple proxy of the return on wealth, the return on stock wealth may not be sufficient, as it neglects the return on human capital. However, high frequency measures of the return on human capital are not easily constructed, and we leave exploring this avenue to future research.

In contrast, differences in regional risk appetites and the aftermath of the Asian crisis appear to have had a measurable influence on risk premiums. In particular, the risk appetite measure is generally highly significant for the British pound sterling and euro, and marginally significant across some specifications for the Canadian dollar. The dummy for the Asia crisis is significant for all currencies except the Canadian dollar.

The importance of the risk appetite and the Asian crisis variables suggests that U.S. financial markets attracted the large savings pool created by the Asian crisis. Indeed, Caballero, Farhi, and Gourinchas (2006) show how, in the context of a multi-region model, low long real rates and the rising share of US assets in global portfolios can be rationalized as an equilibrium outcome in response to regional differences in potential growth and the reduced capacity of Asia to generate financial assets. While we do not find that differences in growth rates are significant, the importance of the risk appetite variable for European and U.K. investors suggests that U.S. financial markets have offered a large array of assets of different risk/return characteristics that are simply less available in other countries-for example 
ABSs as documented earlier (subsection III.B). Moreover, capital flows from Asia into U.S. treasury bonds could reflect "safe haven" effects and the role of the dollar as a reserve currency.

The regressions provide a better fit for the euro than for the yen, suggesting other structural factors could be driving risk premiums in Japan. For Japan, coefficients on sustainability and foreign exchange risk premium measures are wrongly signed, and the risk appetite measure is insignificant. Brooks, Edison, Kumar and Sløk (2001) find similar issues when trying to estimate the role of capital flows in exchange rate equations for the yen and euro area. They argue that because of the fragility of the Japanese financial system, banks or insurance companies may have been more focused on their capital base than on maximizing rates of return. This may have been compounded by structural impediments to portfolio outflowssuch as restrictions on holdings of foreign assets by government-run financial institutions and the pension system-leading to a high level of home bias. Reassuringly, some of these impediments have been removed and home bias is declining in Japan (IMF, 2005).

\begin{tabular}{|c|c|c|c|c|c|c|c|}
\hline \multirow{2}{*}{$\begin{array}{l}\text { Dependent variable: } \\
\text { Bilateral risk premium against euro } \\
\text { Constant }\end{array}$} & \multirow{2}{*}{$\begin{array}{l}\text { Baseline } \\
-36.449 * * * \\
-7.991\end{array}$} & \multicolumn{3}{|c|}{ Growth measure } & \multicolumn{2}{|c|}{ Sustainability } & \multirow{2}{*}{$\begin{array}{c}\text { Risk appetite } \\
-28.189 * * * \\
-5.817\end{array}$} \\
\hline & & $\begin{array}{c}-17.186 * \\
-4.302\end{array}$ & $\begin{array}{r}-8.589 \\
-1.205\end{array}$ & $\begin{array}{l}-8.724 \\
-1.207\end{array}$ & $\begin{array}{l}-36.549 * * * \\
-7.979\end{array}$ & $\begin{array}{l}-24.405 * * * \\
-9.069\end{array}$ & \\
\hline Expected growth differential (U.S. - Euro Area) & $\begin{array}{l}4.137^{* * *} \\
9.158\end{array}$ & & & & $\begin{array}{l}4.134 * * * \\
9.150\end{array}$ & $\begin{array}{l}1.836^{* * *} \\
4.635\end{array}$ & $\begin{array}{l}2.809^{* * *} \\
6.139\end{array}$ \\
\hline Historical growth differential (U.S. - Euro Area) & & $\begin{array}{l}1.573 \text { ** } \\
2.539\end{array}$ & & & & & \\
\hline OECD leading indicator differential lagged & & & $\begin{array}{l}-0.451 * * \\
-2.327\end{array}$ & & & & \\
\hline Relative stock market return (U.S. - Euro Area) & & & & $\begin{array}{l}0.016 \\
0.282\end{array}$ & & & \\
\hline Relative NFA position (U.S. -Euro Area) & $\begin{array}{l}-0.823 * * * \\
-6.538\end{array}$ & $\begin{array}{l}-0.676 * * * \\
-4.248\end{array}$ & $\begin{array}{l}-0.207 \\
-0.810\end{array}$ & $\begin{array}{l}-0.413 * \\
-1.766\end{array}$ & & & $\begin{array}{l}-0.326 * * * \\
-3.578\end{array}$ \\
\hline U.S. NFA lagged & & & & & $\begin{array}{l}-0.826^{* * *} \\
-6.532\end{array}$ & & \\
\hline U.S. net portfolio assets lagged & & & & & & $\begin{array}{l}-0.868 * * * \\
-6.500\end{array}$ & \\
\hline Correlation $\mathrm{b} / \mathrm{w}$ return on euro and MSCI lagged & $\begin{array}{l}2.031 \\
1.226\end{array}$ & $\begin{array}{l}0.453 \\
0.243\end{array}$ & $\begin{array}{l}-1.478 \\
-0.504\end{array}$ & $\begin{array}{l}-2.485 \\
-0.636\end{array}$ & $\begin{array}{l}2.031 \\
1.225\end{array}$ & $\begin{array}{l}-0.125 \\
-0.116\end{array}$ & $\begin{array}{l}-0.834 \\
-0.557\end{array}$ \\
\hline Share of treasury bonds holding lagged (in percent) & $\begin{array}{l}0.727^{* * *} \\
9.545^{*}\end{array}$ & $\begin{array}{l}0.345^{* * *} \\
5.259\end{array}$ & $\begin{array}{l}0.201 \\
1.411\end{array}$ & $\begin{array}{l}0.286 \text { ** } \\
2.516\end{array}$ & $\begin{array}{l}0.729 * * * \\
9.526\end{array}$ & $\begin{array}{l}0.527 \text { *** } \\
10.981\end{array}$ & \\
\hline Share of agency and treasury bonds holding lagged (in percent) & & & & & & & $\begin{array}{l}0.599 * * * \\
7.236\end{array}$ \\
\hline Asian crisis dummy & $\begin{array}{l}-2.507 * * \\
-2.401 \\
\end{array}$ & $\begin{array}{l}-8.478 * * * \\
-3.599\end{array}$ & $\begin{array}{l}-3.852 * \\
-1.930 \\
\end{array}$ & $\begin{array}{l}-7.219 * * * \\
-4.001\end{array}$ & $\begin{array}{l}-2.512 * * \\
-2.407\end{array}$ & $\begin{array}{l}-5.003 * * * \\
-3.397\end{array}$ & $\begin{array}{l}-2.335 * * \\
-2.045 \\
\end{array}$ \\
\hline R-squared & 0.882 & 0.783 & 0.720 & 0.681 & 0.882 & 0.863 & 0.857 \\
\hline
\end{tabular}




\begin{tabular}{|c|c|c|c|c|c|c|c|}
\hline \multirow{2}{*}{$\begin{array}{l}\text { Dependent variable: } \\
\text { Bilateral risk premium against Japanese yen } \\
\text { Constant }\end{array}$} & \multirow{2}{*}{$\begin{array}{c}\text { Baseline } \\
15.265 \\
1.673\end{array}$} & \multicolumn{3}{|c|}{ Growth measure } & \multicolumn{2}{|c|}{ Sustainability } & \multirow{2}{*}{$\begin{array}{c}\text { Risk appetite } \\
4.971 \\
0.423\end{array}$} \\
\hline & & $\begin{array}{c}18.532 * \\
1.760\end{array}$ & $\begin{array}{r}20.812 \\
1.573\end{array}$ & $\begin{array}{c}22.032 * \\
1.791\end{array}$ & $\begin{array}{c}17.526 * \\
1.989\end{array}$ & $\begin{array}{r}11.452 \\
1.396\end{array}$ & \\
\hline Expected growth differential (U.S. - Japan) & $\begin{array}{l}2.084 * * * \\
3.753\end{array}$ & & & & $\begin{array}{l}1.945 * * * \\
3.521\end{array}$ & $\begin{array}{l}2.165^{* * *} \\
4.472\end{array}$ & $\begin{array}{l}2.137^{* * *} \\
4.326\end{array}$ \\
\hline Historical growth differential (U.S. - Japan) & & $\begin{array}{l}1.105 \text { ** } \\
2.341\end{array}$ & & & & & \\
\hline OECD leading indicator differential lagged & & & $\begin{array}{l}-0.023 \\
-0.111\end{array}$ & & & & \\
\hline Relative stock market return (U.S. - Japan) & & & & $\begin{array}{l}0.005 \\
0.219\end{array}$ & & & \\
\hline Relative NFA position (U.S. -Japan) & $\begin{array}{l}0.129 * * * \\
2.965\end{array}$ & $\begin{array}{l}0.093 \\
1.648\end{array}$ & $\begin{array}{l}0.184^{* *} \\
2.465\end{array}$ & $\begin{array}{l}0.189 * * * \\
3.478\end{array}$ & & & $\begin{array}{l}0.129 \text { *** } \\
2.803\end{array}$ \\
\hline U.S. NFA lagged & & & & & $\begin{array}{l}0.323 \text { *** } \\
2.746\end{array}$ & & \\
\hline U.S. net portfolio assets lagged & & & & & & $\begin{array}{l}0.365 * * * \\
2.736\end{array}$ & \\
\hline Correlation $\mathrm{b} / \mathrm{w}$ return on yen and MSCI lagged & $\begin{array}{l}-3.111 * * \\
-2.454\end{array}$ & $\begin{array}{l}-3.297 * \\
-1.874\end{array}$ & $\begin{array}{l}-3.792 * * \\
-2.250\end{array}$ & $\begin{array}{l}-3.743 * * \\
-2.212\end{array}$ & $\begin{array}{l}-3.327 \text { ** } \\
-2.506\end{array}$ & $\begin{array}{l}-2.705 \text { ** } \\
-2.090\end{array}$ & $\begin{array}{l}-3.684 * * * \\
-2.786\end{array}$ \\
\hline Share of treasury bonds holding lagged (in percent) & $\begin{array}{l}-0.127 \\
-0.822\end{array}$ & $\begin{array}{l}-0.172 \\
-0.959\end{array}$ & $\begin{array}{l}-0.176 \\
-0.822\end{array}$ & $\begin{array}{l}-0.189 \\
-0.866\end{array}$ & $\begin{array}{l}-0.183 \\
-1.222\end{array}$ & $\begin{array}{l}-0.082 \\
-0.567\end{array}$ & \\
\hline Share of agency and treasury bonds holding lagged (in percent) & & & & & & & $\begin{array}{l}0.042 \\
0.250\end{array}$ \\
\hline Asian crisis dummy & $\begin{array}{l}-4.952 * * \\
-2.420\end{array}$ & $\begin{array}{l}-5.366 * * \\
-2.434\end{array}$ & $\begin{array}{l}-0.670 \\
-0.250\end{array}$ & $\begin{array}{l}-0.967 \\
-0.457\end{array}$ & $\begin{array}{l}-4.590 \text { ** } \\
-2.133\end{array}$ & $\begin{array}{l}-4.605 * * \\
-2.163\end{array}$ & $\begin{array}{l}-4.600 * * \\
-2.384\end{array}$ \\
\hline R-squared & 0.627 & 0.568 & 0.475 & 0.475 & 0.630 & 0.627 & 0.619 \\
\hline
\end{tabular}

\begin{tabular}{|c|c|c|c|c|c|c|c|}
\hline \multirow{2}{*}{$\begin{array}{l}\text { Dependent variable: } \\
\text { Bilateral risk premium against British pound } \\
\text { Constant }\end{array}$} & \multirow{2}{*}{$\begin{array}{c}\text { Baseline } \\
-3.973 * * * \\
4.297\end{array}$} & \multicolumn{3}{|c|}{ Growth measure } & \multicolumn{2}{|c|}{ Sustainability } & \multirow{2}{*}{$\begin{array}{c}\text { Risk appetite } \\
-4.962 * * * \\
-4.929\end{array}$} \\
\hline & & $\begin{array}{l}-3.864 * * \\
-2.073\end{array}$ & $\begin{array}{l}-2.201 \\
-1.438\end{array}$ & $\begin{array}{l}-3.162 * * * \\
-4.333\end{array}$ & $\begin{array}{l}-3.974 * * * \\
-4.286\end{array}$ & $\begin{array}{l}-4.061 * * * \\
-4.106\end{array}$ & \\
\hline Expected growth differential (U.S. - U.K.) & $\begin{array}{l}0.291 \\
1.046\end{array}$ & & & & $\begin{array}{l}0.291 \\
1.043\end{array}$ & $\begin{array}{l}0.178 \\
0.890\end{array}$ & $\begin{array}{l}0.318 \\
1.122\end{array}$ \\
\hline Historical growth differential (U.S. - U.K.) & & $\begin{array}{l}0.045 \\
0.106\end{array}$ & & & & & \\
\hline OECD leading indicator differential lagged & & & $\begin{array}{l}0.127 \\
1.166\end{array}$ & & & & \\
\hline Relative stock market return (U.S. - U.K.) & & & & $\begin{array}{l}0.025 \\
1.661\end{array}$ & & & \\
\hline Relative NFA position (U.S. -U.K.) & $\begin{array}{l}-0.073 \\
-1.237\end{array}$ & $\begin{array}{l}-0.054 \\
-0.537\end{array}$ & $\begin{array}{l}-0.048 \\
-0.953\end{array}$ & $\begin{array}{l}-0.028 \\
-0.669\end{array}$ & & & $\begin{array}{r}-0.074 \\
-1.215\end{array}$ \\
\hline U.S. NFA lagged & & & & & $\begin{array}{l}-0.073 \\
-1.229\end{array}$ & & \\
\hline U.S. net portfolio assets lagged & & & & & & $\begin{array}{l}-0.102 \\
-1.178\end{array}$ & \\
\hline Correlation $\mathrm{b} / \mathrm{w}$ return on British pound and MSCI lagged & $\begin{array}{l}-0.699 \\
-0.981\end{array}$ & $\begin{array}{l}-0.637 \\
-0.897\end{array}$ & $\begin{array}{l}-0.875 \\
-1.267\end{array}$ & $\begin{array}{l}-0.514 \\
-0.602\end{array}$ & $\begin{array}{l}-0.699 \\
-0.980\end{array}$ & $\begin{array}{r}-0.794 \\
-1.219\end{array}$ & $\begin{array}{l}-0.841 \\
-1.182\end{array}$ \\
\hline Share of treasury bonds holding lagged (in percent) & $\begin{array}{l}0.186^{* * *} \\
7.825\end{array}$ & $\begin{array}{l}0.177^{* * *} \\
7.205\end{array}$ & $\begin{array}{l}0.195^{* * *} \\
6.655\end{array}$ & $\begin{array}{l}0.154^{* * *} \\
7.033\end{array}$ & $\begin{array}{l}0.186^{* * *} \\
7.797\end{array}$ & $\begin{array}{l}0.185^{* * *} \\
8.993\end{array}$ & \\
\hline Share of agency and treasury bonds holding lagged (in percent) & & & & & & & $\begin{array}{l}0.176 * * * \\
8.581\end{array}$ \\
\hline Asian crisis dummy & $\begin{array}{l}-2.342 * * \\
-2.705\end{array}$ & $\begin{array}{l}-1.919 * \\
-1.861\end{array}$ & $\begin{array}{l}-3.267 * \\
-1.931\end{array}$ & $\begin{array}{l}-1.664 * * * \\
-2.913\end{array}$ & $\begin{array}{l}-2.341 * * \\
-2.694\end{array}$ & $\begin{array}{l}-2.349 * * * \\
-3.138\end{array}$ & $\begin{array}{l}-2.274 * * \\
-2.629\end{array}$ \\
\hline R-squared & 0.779 & 0.772 & 0.790 & 0.781 & 0.778 & 0.786 & 0.771 \\
\hline
\end{tabular}




\begin{tabular}{|c|c|c|c|c|c|c|c|}
\hline \multirow{2}{*}{$\begin{array}{l}\text { Dependent variable: } \\
\text { Bilateral risk premium against Canadian dollar } \\
\text { Constant }\end{array}$} & \multirow{2}{*}{$\begin{array}{l}\text { Baseline } \\
-3.334^{*} \\
-2.025\end{array}$} & \multicolumn{3}{|c|}{ Growth measure } & \multicolumn{2}{|c|}{ Sustainability } & \multirow{2}{*}{$\begin{array}{c}\text { Risk appetite } \\
-1.342 \\
-1.304\end{array}$} \\
\hline & & $\begin{array}{l}-4.765 * \\
-3.124\end{array}$ & $\begin{array}{l}-3.763 * \\
-1.802\end{array}$ & $\begin{array}{l}-3.736 \text { *** } \\
-1.805\end{array}$ & $\begin{array}{l}-2.545 * \\
-2.006\end{array}$ & $\begin{array}{l}-3.994 * * \\
-2.097\end{array}$ & \\
\hline Expected growth differential (U.S. - Canada) & $\begin{array}{l}1.138^{* * *} \\
2.751\end{array}$ & & & & $\begin{array}{l}1.047 \text { * } \\
2.889\end{array}$ & $\begin{array}{l}0.916 \text { ** } \\
2.303\end{array}$ & $\begin{array}{l}1.122 * * * \\
2.849\end{array}$ \\
\hline Historical growth differential (U.S. - Canada) & & $\begin{array}{l}0.690 \text { *** } \\
3.428\end{array}$ & & & & & \\
\hline OECD leading indicator differential lagged & & & $\begin{array}{l}0.108 \\
0.767\end{array}$ & & & & \\
\hline Relative stock market return (U.S. - Canada) & & & & $\begin{array}{l}0.006 \\
0.593\end{array}$ & & & \\
\hline Relative NFA position (U.S. -Canada) & $\begin{array}{r}0.000 \\
-0.002\end{array}$ & 0.015 & -0.017 & 0.015 & & & 0.046 \\
\hline U.S. NFA lagged & & & & & $\begin{array}{l}0.024 \\
0.571\end{array}$ & & \\
\hline U.S. net portfolio assets lagged & & & & & & $\begin{array}{l}-0.051 \\
-0.622\end{array}$ & \\
\hline Correlation $\mathrm{b} / \mathrm{w}$ return on $\mathrm{CAD}$ and MSCI lagged & $\begin{array}{l}0.183 \\
0.253\end{array}$ & $\begin{array}{l}-0.099 \\
-0.150\end{array}$ & $\begin{array}{l}-0.239 \\
-0.304\end{array}$ & $\begin{array}{l}-0.525 \\
-0.788\end{array}$ & $\begin{array}{l}0.033 \\
0.049\end{array}$ & $\begin{array}{l}-0.084 \\
-0.130\end{array}$ & $\begin{array}{l}0.154 \\
0.240\end{array}$ \\
\hline Share of treasury bonds holding lagged (in percent) & $\begin{array}{l}0.173 * \\
1.746\end{array}$ & $\begin{array}{l}0.239 \text { ** } \\
2.574\end{array}$ & $\begin{array}{l}0.165 \\
1.424\end{array}$ & $\begin{array}{l}0.191 \\
1.528\end{array}$ & $\begin{array}{l}0.123 \\
1.644\end{array}$ & $\begin{array}{l}0.199 * \\
1.810\end{array}$ & \\
\hline Share of agency and treasury bonds holding lagged (in percent) & & & & & & & $\begin{array}{l}0.040 \\
0.596\end{array}$ \\
\hline Asian crisis dummy & $\begin{array}{l}-0.457 \\
-0.500\end{array}$ & $\begin{array}{l}0.478 \\
0.600\end{array}$ & $\begin{array}{l}-0.543 \\
-0.723\end{array}$ & $\begin{array}{l}-0.284 \\
-0.339\end{array}$ & $\begin{array}{l}-0.724 \\
-0.925\end{array}$ & $\begin{array}{l}-0.849 \\
-1.018\end{array}$ & $\begin{array}{l}-1.180 \\
-1.393\end{array}$ \\
\hline R-squared & 0.423 & 0.536 & 0.311 & 0.300 & 0.440 & 0.445 & 0.424 \\
\hline
\end{tabular}

\section{Conclusions ANd Policy Implications}

This paper finds that dollar risk premiums have been generally negative in recent years, exhibiting large fluctuations, especially against the yen and the euro. In general, premiums fell into negative territory toward the end of the 1990s but have since increased toward zero:

- $\quad$ The risk premium vis-à-vis the euro declined to about-10 percent in 2000.

- $\quad$ The risk premium against the yen has generally been positive, but turned negative in recent years - consistent with studies that find Japanese home bias declining from extremely high levels in the past.

- $\quad$ Risk premiums have largely remained negative in recent years as rising expectations of dollar depreciation have been only partly offset by growing interest differentials in favor of the United States.

The negative risk premiums were accompanied by increasing capital flows, with investment patterns differing across regions. The decline in the U.S. net financing position occurred mostly through increases in fixed-income securities, which were purchased largely by investors in the euro area, Japan, and emerging Asian economies. European investors acquired mainly corporate bonds and equity, whereas Japan and emerging Asia invested primarily in treasury bonds. The coincidence of riskier investment patterns and - on occasion-strongly negative risk premiums in the euro-dollar exchange rate suggests that 
European investors may have had a greater risk appetite than Asian investors as far as U.S. assets are concerned.

Regression results also suggest that macroeconomic measures have not had a significant impact on risk premiums, but that differences in regional risk appetites and the Asian crisis are important factors. Sustainability and relative growth prospects measures are generally incorrectly signed or insignificant, and the hedging properties of exchange rate movements against volatility of investors' consumption paths are also insignificant. We find, however, that an increase in risk appetites in the United Kingdom and the euro area-as measured by investors' revealed preference for corporate bonds over safer treasury bonds - tends to go hand in hand with a decline in risk premiums. Risk premiums on the dollar also appear to have fallen in the aftermath of the Asian crisis.

The presence of negative dollar risk premiums amid record capital inflows could suggest that investors may favor U.S. investments for structural reasons. Of course, markets could have simply been irrational in investing in U.S. assets despite negative expected returns, given prevailing interest rates and exchange rate expectations. The analysis of this paper suggests another explanation, however - namely that the Asian crisis created a large pool of savings searching for relatively risk less investment opportunities, which were provided by deep, liquid, and innovative U.S. financial markets with robust investor protection. Moreover, the continued attractiveness of U.S. financial markets to European investors suggests that they offer a large array of assets, with different risk/return characteristics, that facilitate the structuring of diversified investment portfolios.

Studying in detail foreign investment patterns into U.S. nongovernment debt is an important project for future research. Indeed, Table 11 shows that not just in absolute terms, but as a share of GDP, U.S. nongovernment debt markets are bigger than in other major region. Figuring out what kind of nongovernment debt foreign investors have been buying - high grade corporate bonds, junk bonds, agency bonds, or ABSs - and what returns they have been earning is important, as it will help understand in what areas U.S. financial markets offer products that are not currently available elsewhere and to what extent financing is likely to remain easy. 


\begin{tabular}{|c|c|c|c|c|}
\hline \multicolumn{5}{|c|}{$\begin{array}{l}\text { Table 11: Debt Securities Outstanding by } \text { Issuer }^{1} \\
\text { (In percent of GDP) }\end{array}$} \\
\hline & \multicolumn{4}{|c|}{ Financial Institutions and Corporate Issuers } \\
\hline & $\begin{array}{l}\text { United } \\
\text { States }\end{array}$ & Euro Area & Japan & $\begin{array}{l}\text { United } \\
\text { Kingdom }\end{array}$ \\
\hline 1995 & 87.4 & 50.6 & 52.3 & 30.8 \\
\hline 2000 & 121.6 & 72.7 & 54.2 & 56.0 \\
\hline 2005 & 140.1 & 98.0 & 49.5 & 88.3 \\
\hline \multicolumn{5}{|c|}{ Source: Bank for International Settlements. } \\
\hline \multicolumn{5}{|c|}{${ }^{1}$ Includes domestic and international debt securities of local issuers. } \\
\hline
\end{tabular}

Looking forward, the allocative efficiency of U.S financial markets could mitigate risks of a disorderly unwinding of global current account imbalances. Adverse adjustment scenarios would include a risk that foreign investors might buy fewer U.S. treasury bonds unless risk premiums on the dollar increase sharply, driving dollar depreciation as well as increases in relative interest rates in the United States. In particular, official flows into treasury bonds may decline as some major emerging market central banks approach their desired levels of reserves. The risks of such an adverse scenario are likely to be reduced, however, by the dollar's role as the global reserve currency and the attractiveness of the U.S. financial system. To be sure, for the latter characteristic to continue, U.S. financial markets will likely have to continue innovating to retain their advantage over other financial markets and, thus, provide foreign investors with the assets they desire. An "orderly" scenario would also be supported by (i) improving economic prospects and, consequently, increasing risk appetite in other regions, which should lead to a demand for riskier U.S. assets; and (ii) a continued reduction in home bias in Japan. 


\title{
DAta AND REgRession Methodology
}

\begin{abstract}
A. Data
This section highlights further details on data and their sources, sample composition, and empirical approaches to constructing specific variables. The sample comprises quarterly data for 1989-2005.
\end{abstract}

\section{Risk premiums}

Major currencies. We constructed bilateral risk premiums, at 3 months, one-year and 2-year horizons, for the U.S. dollar against the British pound sterling, Canadian dollar, euro, and Japanese yen. At the one year horizon, the measures relied on Eurocurrency deposits' interest rates from DataStream and one year ahead currency exchange rate forecasts from Consensus Economics monthly surveys. As Consensus' surveys are conducted on the second Monday of the month, interest rate differentials corresponded to the date of the survey. Robustness checks with exchange rate spot rates and interest rate differentials smoothed around the survey date were also conducted. Our global sample is limited to the first Consensus survey conducted in October 1989.

Euro area. For the euro area, we used the deutschemark pre-1999 exchange rate as Consensus only had currency forecasts for the deutschemark/U.S. dollar rate before the introduction of the euro. This series was spliced with the euro post-1999 using the deutschemark/euro conversion factor.

Other industrial and emerging market countries. We further constructed bilateral risk premiums against the Australian dollar, Brazilian real, Hong Kong dollar, Indian rupee, Indonesian rupeah, Malaysian rupee, Mexican peso, New Zealand dollar, Korean won, Philippine peso, and Thai baht. Most of these currencies have been surveyed by Consensus on a monthly basis since 1990, which allowed us to construct series of monthly risk premiums. Surveys on Latin America were only conducted on a bi-monthly basis before 2000. However, interest rate data for many of these countries was difficult to obtain and usually only available from the late 1990s. Eurocurrency deposit rates were used where available, though we mainly relied on the generic rates on government bonds from Bloomberg.

Multilateral risk premium measures. We constructed two multilateral measure of U.S. dollar risk premiums, a narrow and broad measure. The weights used in the measures relied on respective country shares in total U.S. trade. The import and export flows were normalized by the total trade with the countries included in the measure. The narrow measure covers the major four currencies, while the broad one adds the other eleven currencies, the latter for a much shorter time horizon (starting in 2000). 


\section{Other data}

Expected growth differentials. Consensus growth forecasts are limited to current and next calendar years annual rates. One year ahead growth differential were constructed as a weighted sum of current and next year growth differentials with a weight on the current year corresponding to the number of quarters left in the current year.

Capital flows. The regional flows and positions aggregates for Emerging Asia cover Hong Kong SAR, China, India, Indonesia, the Republic of Korea, Malaysia, the Philippines, Taiwan Province of China, Thailand, and Singapore. The Latin American region comprises Argentina, Brazil, Chile, Colombia, Mexico, Peru, Venezuela, and some other smaller countries. The Caribbean Basin was not included in the Latin American Region due to a strong custodial bias in capital flows to and from their offshore centers. We used average and total quarterly aggregates for positions and flows respectively.

Net foreign assets position. We followed the methodology outlined in the WEO (IMF 2005) to quarterly interpolated NFAs. The quarterly interpolation for Euro area NFA position used euro area annual NFAs from Wealth of Nation dataset by Lane and Milesi-Ferretti (2005).

Covariances. As mentioned in the main text, we used the return on the MSCI global equity index as a proxy for consumption of a "world" investor and constructed the covariance of the index return with bilateral U.S. dollar appreciation against the major currencies. Ideally, the total return on the index should have accounted for price gains and dividend yields. However, MSCI dividend yield data was available through DataStream beginning in December 1995, so we considered only index price gains in constructing covariances. Our covariance estimates used year-on-year monthly returns on the index and year-on-year dollar changes calculated over the two year period. While this choice might appear arbitrary, the robustness checks with different periods for the covariance calculation as well as month-on-month rates of return produced results with comparable or inferior statistical significance to those reported.

Other variables. Other data included OECD leading indicators and relative local stock market returns in local currency for DJ65, Topix, FTSE250 and STOXX50 from DataStream.

\section{B. Regression Methodology}

In our baseline specification, we regressed levels of bilateral risk premiums on a constant, expected growth differentials, the relative net foreign assets position, the covariance of the return on the MSCI index and U.S. dollar changes, the share of treasury bonds in a country's gross holding of U.S. assets, and an Asian crisis dummy variable. Alternative specifications used different growth, U.S. sustainability, and risk appetite for U.S. assets measures. Historical variables such as growth, the OECD leading indicators differential, sustainability, return correlations, and risk appetite measures enter in lags. Reported standard errors are Newey-West heteroscedasticity-consistent. It should be noted that the intercept parameter estimates lack meaningful interpretation, as they are partly capturing steady state effects of the other explanatory variables. 


\section{References}

Ayuso, J., and F. Restoy, 1996, "Interest Rate Parity and Foreign Exchange Risk Premia in the ERM.” Journal of International Money and Finance, Vol. 15 (June), pp. 369-82.

Balakrishnan, R., and J.J. Groen, 2006 “Asset Price Based Estimates of Sterling Exchange Rate Risk Premia,” Journal of International Money and Finance, Vol. 25, pp. 71-92.

Bernanke, B., 2005, "The Global Saving Glut and the U.S. Current Account Deficit," Sandridge Lecture delivered to the Virginia Association of Economists, Richmond (March 10). Available on the Web at http://www.federalreserve.gov/boarddocs/ speeches/2005/200503102/default.htm.

Blanchard, O., F. Giavazzi, and F. Sa, 2005, "International Investors, the U.S. Current Account, and the Dollar," Brookings Papers on Economic Activity, Brookings Institution, Vol. 1, pp. 1-49.

Bofinger, P., and R. Schmidt, 2004, "Should One Rely on Professional Exchange Rate Forecasts? An Empirical Analysis of Professional Forecasts for the Euro/Dollar Rate" CEPR Discussion Paper No. 4235 (London: Centre for Economic Policy Research).

Brooks, R., H. Edison, M. Kumar, and T. Sløk, 2001, "Exchange Rates and Capital Flows," IMF Working Paper 01/190 (Washington: International Monetary Fund).

Caballero, R., E. Farhi, and P. Gourinchas, 2006, “An Equilibrium Model of Global Imbalances and Low Interest Rates," (unpublished; Cambridge, Massachusetts: Massachusetts Institute of Technology).

Campbell, J.Y., 1993. "Intertemporal Asset Pricing Without Consumption Data," American Economic Review, Vol. 83, pp. 487-512.

Cerisola, M., H. Faruqee, and A. Keenan, 1999, "Long-Term Sustainability of the U.S, Current Account Balance", in "United States: Selected Issues", IMF Staff Country Report 99/101 (Washington: International Monetary Fund).

Chinn, M., and J. Frankel, 2004, "Patterns in Exchange Rate Forecasts for Twenty-Five Currencies," Journal of Money, Credit, and Banking, Vol. 26, pp. 759-70.

Chinn, M., J. Rogers, and F. Warnock, 2006, "Exchange Rates and External Asset Positions," (unpublished, Washington: Board of Governors of the Federal Reserve System).

Cochrane J.H., 2001, Asset Pricing (Princeton, New Jersey and Oxford, United Kingdom: Princeton University Press). 
Gruber, J. and S. Kamin, 2005, "Explaining the Global Pattern of Current Account Imbalances," International Finance Discussion Paper No. 846 (Washington: Board of Governors of the Federal Reserve System).

International Monetary Fund, 2006a, Global Financial Stability Report, World Economic and Financial Surveys (Washington).

_ , 2006b, "Globalization and External Imbalances” World Economic Outlook, April (Washington).

— , 2005, Japan: Selected Issues, IMF Staff Country Report 05/272, (Washington).

Krugman, P., 2006, “Will There Be a Dollar Crisis?,” (unpublished; New York: Columbia University).

Lettau, M., and S. Ludvigson., 2001, "Resurrecting the (C)CAPM: A Cross-Sectional Test When Risk Premia are Time-Varying," Journal of Political Economy, Vol. 109, pp. 1238-87.

Merton, R.C., 1973, “An Intertemporal Capital Asset Pricing Model,” Econometrica, Vol. 41, pp. 867-87.

Obstfeld, M., and K. Rogoff, 2005, "Global Current Account Imbalances and Exchange Rate Adjustments," Brookings Papers on Economic Activity Vol. 1, pp. 67-123.

Thomas, C., F. Warnock, and J. Wongswan, 2006,'The Performance of International Portfolios," NBER Working Paper No. 12346 (Cambridge, Massachusetts: National Bureau of Economic Research).

Wadhwani, S.,1999, "Currency Puzzles," speech given at the London School of Economics. Available on the Web at http://www.bankofengland.co.uk/publications/speeches/1999/speech53.pdf.

Warnock, F., and C. Cleaver, 2002 "Financial Centers and the Geography of Capital Flows," International Finance Discussion Paper, No. 722 (Washington: Board of Governors of the Federal Reserve System). 